\title{
Riverine people's knowledge of the Vulnerable Amazonian manatee Trichechus inunguis in contrasting protected areas
}

\author{
Luciana Carvalho Crema, Vera Maria Ferreira da Silva \\ and Maria Teresa Fernandez Piedade
}

\begin{abstract}
Traditional knowledge gained through daily interactions with the environment can yield insights into processes at temporal or spatial scales that may be overlooked by conventional scientific research. Ninety interviews were conducted with riverine people in the vicinity of Anavilhanas National Park, Tapajós-Arapiuns Extractive Reserve and Tapajós National Forest in the Brazilian Amazon, with the aim to increase knowledge of the feeding habits of the Amazonian manatee Trichechus inunguis and evaluate its conservation status in contrasting protected areas. In Anavilhanas respondents identified 31 plant species consumed by the manatee, of which vines had the highest cognitive salience index value (the summed importance of each plant species), even though they are available to manatees only during the high-water season. In the Tapajós region 37 plant species were identified, with submerged species with floating leaves being the main component of the manatee's diet. Although hunting has declined it still occurs in Anavilhanas, which is susceptible to environmental crimes because of its proximity to urban centres. Manatee hunting seems to be infrequent in the Tapajós region, having little impact on the population. Given the broad knowledge within the local community about the Amazonian manatee, involvement of riverine people in manatee conservation activities is fundamental for reducing threats and increasing conservation effectiveness.
\end{abstract}

Keywords Amazonian manatee, Brazil, ethnobiology, feeding habits, interview, Rio Negro, Rio Tapajós, Trichechus inunguis

Supplementary material for this article is available at https://doi.org/10.1017/So030605318000686

\footnotetext{
Luciana Carvalho Crema* (Corresponding author) Vera Maria Ferreira da Silva and Maria Teresa Fernandez Piedade Instituto Nacional de Pesquisas da Amazônia Manaus, Amazonas, Brazil

E-mail luciana.carvalho.crema@gmail.com

*Also at: Centro Nacional de Pesquisa e Conservação da Biodiversidade Amazônica, Instituto Chico Mendes de Conservação da Biodiversidade, Manaus, Amazonas, Brazil

Received o5 February 2018. Revision requested 16 April 2018.

Accepted 2 May 2018. First published online 8 April 2019.
}

\section{Introduction}

7 raditional knowledge is a cumulative body of expertise, 1 awareness and beliefs, culturally transmitted across generations, concerning the relationships of living beings among themselves and with their environment (Berkes et al., 2000). Originating from daily interactions with the environment (Fabricius \& Koch, 2004), it underpins an understanding of ecosystem processes at temporal and spatial scales that would be difficult to record by conventional scientific research (Huntington, 2000). Traditional knowledge can therefore guide efforts towards the protection of habitats, supporting conservation actions at the species level (Huntington, 2000; Rajamani, 2013).

The Amazonian manatee Trichechus inunguis has been the most hunted aquatic mammal in Brazil since pre-colonial times (da Silva et al., 2008) and consequently has suffered significant decline. It is categorized as Vulnerable on the national list of threatened species and the IUCN Red List (MMA, 2014; Marmontel et al., 2016), and is listed in Appendix I of CITES (CITES, 2017). Despite a decrease in hunting (Marmontel et al., 2012), the consumption of manatee meat is still customary in the Amazon (ICMBio, 2011).

This aquatic mammal lives its entire life in the water, reaches up to $3 \mathrm{~m}$ in length and $420 \mathrm{~kg}$ (Amaral et al., 2010), and is herbivorous, feeding on macrophytes, roots and vegetation from floodplains (Best, 1984; GuterresPazin et al., 2014) with distinct physical and chemical properties, such as black and clearwater, flooded forests (igapós), and whitewater rivers (várzeas; Best, 1983; Rosas, 1994). The differences between these environments are paralleled in the variations in richness and diversity of plants the manatee feeds upon (Crema, 2017).

Studying the Amazonian manatee is challenging because of its cryptic behaviour, the turbidity of its favoured habitats (Best, 1984; Rosas, 1994) and its ability to spend long periods beneath banks of aquatic macrophytes (Junk \& da Silva, 1997). However, people living in riverine communities have been able to share detailed knowledge about this species because historically they have shared and used the same environment (Calvimontes \& Marmontel, 2010).

We sought to elicit traditional knowledge about T. inunguis (places of occurrence, reproductive season, diet, hunting, cultural importance) in federal protected areas in black and clearwater igapós in the Brazilian Amazon, to answer the following questions: (1) Are the diet of T. inunguis and 
the floristic composition of its habitat determined by the characteristics of each specific igapó? (2) Can traditional knowledge improve our scientific knowledge of the biology and conservation of the Amazonian manatee?

\section{Study areas}

The study was conducted in two regions: (1) Anavilhanas National Park, including residents of the municipality of Novo Airão and 14 communities of three protected areas in Amazonas State (the Environmental Protection Area on the right bank of the Rio Negro Paduari-Solimões Sector, the North Sector of Rio Negro State Park, and the Environmental Protection Area on the left bank of the Rio Negro Aturiá-Apuauzinho Sector); (2) the Tapajós region, where residents from six communities of the TapajósArapiuns Extractive Reserve and three communities of the Tapajós National Forest were interviewed.

Anavilhanas $(647,610 \mathrm{ha})$ is an area of integral protection in the municipality of Novo Airão, $60 \mathrm{~km}$ from Manaus (ICMBio, 2017). It was established as an Ecological Station in 1981 and designated a National Park in 2008. The majority of its area comprises seasonally flooded, fluvial islands, and the remainder is unflooded terra firme forest. The Tapajós National Forest (600,00o ha) was established in 1974 in the municipalities of Aveiro, Belterra, Rurópolis and Placas, Pará State (IBAMA, 2004). The Tapajós-Arapiuns Extractive Reserve $(647,610$ ha) was created in 1998 in the municipalities of Santarém and Aveiro, Pará State (ICMBio, 2014). In Tapajós National Forest and Tapajós-Arapiuns Extractive Reserve, separated by the Rio Tapajós, sustainable use of natural resources is permitted; both banks of the Rio Tapajós are largely covered by terra firme forest, with ria lakes and thin strips of igapó forest.

\section{Methods}

We selected interviewees from among the caboclos, the riverine people whose ancestry is a mix of Indigenous, Afro-Brazilian and European peoples (Lima-Ayres, 1992). Interviewees were selected according to three criteria: (1) experience in hunting manatees, or any direct contact with the species, (2) at least 19 years living in the area, and (3) the recommendation of community leaders. Interviews were conducted between March 2012 and October 2014, with 29 men and one woman in Anavilhanas, 34 men and four women in Tapajós-Arapiuns Extractive Reserve, and 19 men and three women in Tapajós National Forest (90 participants in total).

The interviews were semi-structured (Supplementary Material 1) and included questions about the occurrence and biology of the Amazonian manatee, focusing in particular on its feeding ecology. Part of the interview consisted of a free-listing activity (Borgatti, 1998; Albuquerque et al., 2014) in which the interviewees listed plants eaten by the manatee (Best, 1981; Colares \& Colares, 2002; Franzini et al., 2013; Guterres-Pazin et al., 2014). A board with 39 photographs of plant species of the region was shown, and interviewees were asked to name the plants. Maps were created based on observations by the interviewees of manatees and signs of manatee occurrence (faeces, feeding traces, mortality).

In addition, we identified the locations of comidias (feeding areas), which are open areas in the aquatic vegetation resulting from the feeding of manatees (Calvimontes \& Marmontel, 2010). Aquatic macrophyte vegetation was surveyed using line transects along the vegetated margins of lakes, as described by Crema (2017). In Anavilhanas 43 sites of occurrence were identified, five of them outside the protected area (Fig. 1a); 30 sites were recorded in the Tapajós region (Fig. 1b). We grouped plant species based on life-form (adapted from Junk, 1986), following the nomenclature of Forzza et al. (2016). Plant species identified from the 73 sites were deposited in the herbarium at the Federal University of Amazonas (HUAM, Manaus, Brazil).

The data from the listing of plant species by interviewees were used to calculate a cognitive salience index (Sutrop, 2001). This index $(S)$ represents the summed importance of each plant, combining the frequency of citation of an item $(F)$ in interviews with its mean position on all lists $(\mathrm{mP}): S=F /(\mathrm{N} \times \mathrm{mP})$, where $\mathrm{N}$ is the total number of the plant species named during the interviews.

\section{Results}

Interviewees were aged 32-83 years in Anavilhanas and 19-82 in the Tapajós region. None of the respondents claimed to be engaged in manatee hunting activity at the time of the interviews, but four indicated they had hunted when they were younger. Twenty per cent of the interviewees reported having seen manatees in the previous 2 years in Anavilhanas, and $56 \%$ in the Tapajós region (Table 1 ). The number of manatees reported killed by hunting in the previous 10 years was much higher in Anavilhanas (30\% of the interviewees) than in Tapajós ( $5 \%$; Table 1); the high-water season was considered to be the best time to see manatees (59\% in Anavilhanas; $80 \%$ in Tapajós; Table 1).

Most interviewees ( $72 \%$ in Anavilhanas and $32 \%$ in Tapajós) stated that manatees move in pairs, often a female with a calf. In Tapajós $40 \%$ had seen groups of up to four individuals; in Anavilhanas larger groups had been seen (33\%; Table 1). In Anavilhanas and Tapajós $68 \%$ and $95 \%$ of interviewees, respectively, stated that during the low-water season the species migrates to deeper water areas (poços) and to the riverbeds. In Anavilhanas $81 \%$ of interviewees indicated they had not observed manatee sexual activity, whereas in Tapajós $60 \%$ said that this occurs during the flooding season (Table 1 ). 

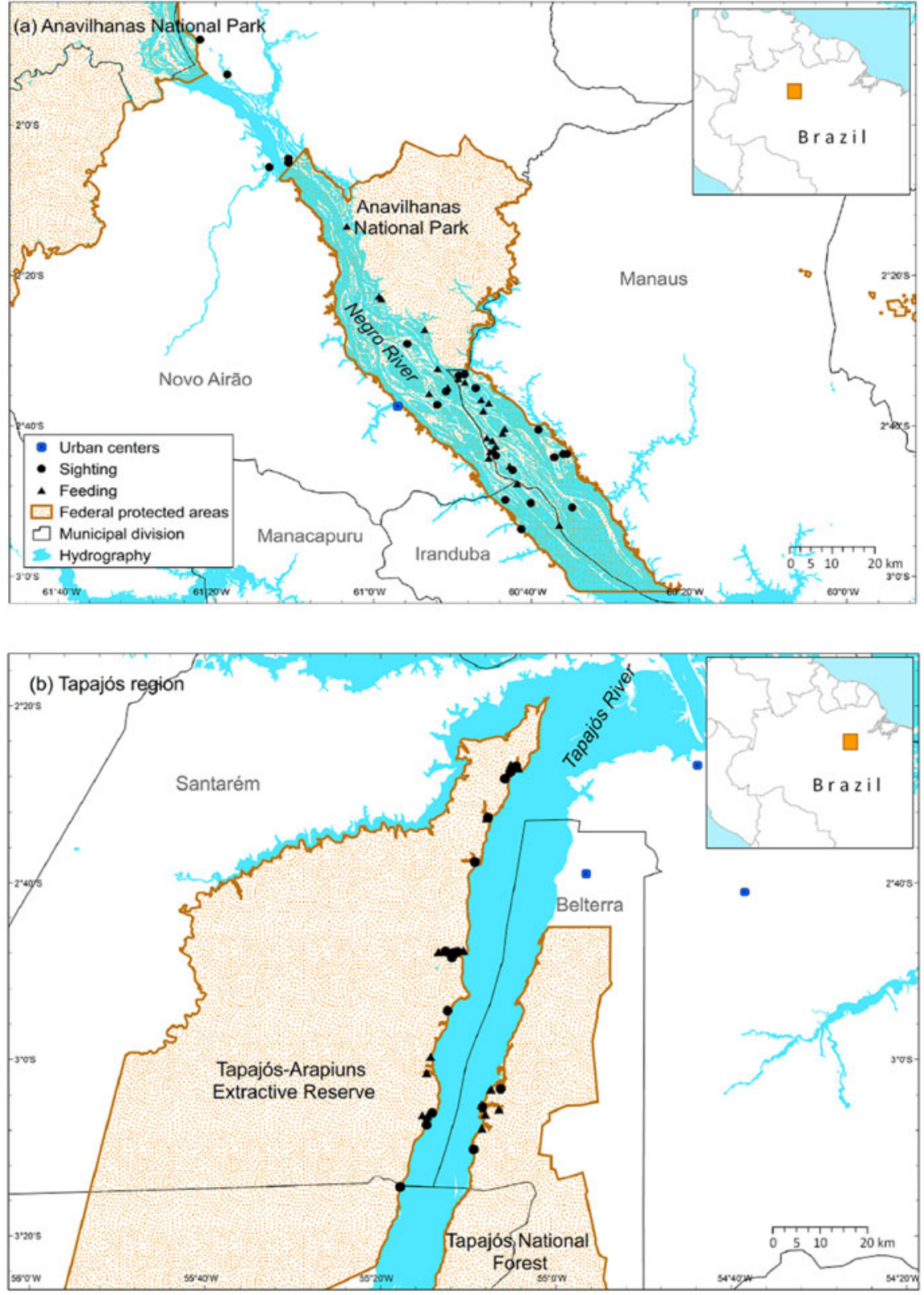

FIG. 1 Locations of sightings and evidence of feeding of the Amazonian manatee Trichechus inunguis in (a) Anavilhanas National Park and (b) protected areas in the Tapajós region.
Feeding habits

Interviewees indicated that 60 plant species are consumed by the Amazonian manatee, 31 in Anavilhanas and 37 in Tapajós, with 12 species common to both areas (Table 2). Seventeen of the plant species (mainly vines) cited by interviewees were not in the photographs shown, but the interviewees described the plants in detail and we were able to collect them. In Anavilhanas the plant species with the highest cognitive salience index values were the vines IPomoea alba, Mikania micrantha, Tassadia berteriana and Mesechites trifida, followed by the shrub Coccoloba pichuna (Table 3). In Tapajós the plant species with the highest cognitive salience index values were herbaceous plants with floating leaves such as Nymphaea spp., and rooted submerged plants such as Eleocharis minima and Eleocharis fluctuans (Table 3). In Tapajós $70 \%$ of the respondents indicated that manatees also feed on submerged plant roots, mainly of Nymphaea spp.

\section{Hunting}

Hunting was reported by interviewees to be the main cause of death of the species (62\% of interviewees in Anavilhanas and $52 \%$ in Tapajós), but in Tapajós $16 \%$ of interviewees also reported that manatees died from stranding and entanglement in fishing nets (Table 1). Most hunting records predate 2003 ( 42 and $75 \%$ in Anavilhanas and Tapajós, respectively; Table 1). In Anavilhanas $26 \%$ of respondents were aware of hunting events, compared to $2 \%$ in Tapajós. The harpoon was the most cited hunting instrument, and high-water 
TABLE 1 Principal responses to questions, provided by riverine people in Anavilhanas National Park (Fig. 1a) and protected areas in the Tapajós region (Tapajós National Forest and Tapajós-Arapiuns Extractive Reserve; Fig. 1b) in interviews (Supplementary material 1) about the Amazonian manatee Trichechus inunguis, with the number and percentage of interviewees who gave each response.

\begin{tabular}{|c|c|c|c|}
\hline \multirow[b]{2}{*}{ Question } & \multicolumn{3}{|l|}{ No. of responses $(\%)$} \\
\hline & $\begin{array}{l}\text { Anavilhanas National Park } \\
(\mathrm{n}=30)\end{array}$ & $\begin{array}{l}\text { Tapajós protected areas } \\
(\mathrm{n}=60)\end{array}$ & $\begin{array}{l}\text { Total } \\
(\mathrm{n}=90)\end{array}$ \\
\hline \multicolumn{4}{|l|}{ General } \\
\hline Have you seen manatees in the wild in the last 2 years? & $6(20)$ & $34(56)$ & $40(44)$ \\
\hline \multicolumn{4}{|l|}{ Biological } \\
\hline When was the last time you heard of a manatee being hunted? & $9(30)$ & $3(5)$ & $12(13)$ \\
\hline Is the high-water level season the best time to see the species? & $18(59)$ & $48(80)$ & $66(73)$ \\
\hline Do manatees move in pairs? & $22(72)$ & $19(32)$ & $41(46)$ \\
\hline Do manatees move in groups of $>10$ individuals? & $10(33)$ & $24(40)$ & $34(38)$ \\
\hline Do manatees migrate during the low-water season? & $20(68)$ & $57(95)$ & $77(86)$ \\
\hline Do manatees breed during the flood season? & $3(9)$ & $36(60)$ & $39(43)$ \\
\hline \multicolumn{4}{|l|}{ Feeding } \\
\hline Do you know about the manatee's feeding habits? & $29(98)$ & $57(95)$ & $86(96)$ \\
\hline Do manatees mostly consume leaves? & $18(60)$ & $27(45)$ & $45(50)$ \\
\hline Do manatees consume whole plants? & $7(23)$ & $17(29)$ & $24(27)$ \\
\hline Do manatees consume submerged plant roots? & $0(0)$ & $42(70)$ & $42(47)$ \\
\hline \multicolumn{4}{|l|}{ Hunting } \\
\hline Do you know if hunting is the main cause of manatee deaths? & $19(62)$ & $31(52)$ & $50(56)$ \\
\hline $\begin{array}{l}\text { Are stranding \& entanglement in fishing nets a cause of } \\
\text { manateee deaths? }\end{array}$ & $1(3)$ & $10(16)$ & $11(12)$ \\
\hline Is there any hunting preference for male or female manatees? & $29(96)$ & $59(98)$ & $88(98)$ \\
\hline Do you know about any hunting of manatees before $2003 ?$ & $13(42)$ & $45(75)$ & $58(64)$ \\
\hline $\begin{array}{l}\text { Do you have any information about hunting of manatees } \\
\text { during the current year? }\end{array}$ & $8(26)$ & $1(2)$ & $9(10)$ \\
\hline Is the harpoon a traditional hunting instrument? & $30(100)$ & $58(97)$ & $88(98)$ \\
\hline Are manatees most hunted during the high-water season? & $20(68)$ & $54(90)$ & $74(82)$ \\
\hline $\begin{array}{l}\text { Do you know if subsistence is the main motivation for manatee } \\
\text { hunting? }\end{array}$ & $24(80)$ & $51(85)$ & $75(83)$ \\
\hline Have you ever consumed manatee meat? & $15(50)$ & $43(55)$ & $58(64)$ \\
\hline Is manatee fat used in cooking? & $23(77)$ & $55(92)$ & $78(87)$ \\
\hline Do you know any medicinal uses of manatee body parts? & $0(0)$ & $19(32)$ & $19(21)$ \\
\hline Do you know if manatee bones are used as artefacts or tools? & $2(7)$ & $25(42)$ & $27(30)$ \\
\hline
\end{tabular}

season the hydrological phase with the highest hunting intensity (68 and 90\% in Anavilhanas and Tapajós, respectively), although $23 \%$ of respondents in Anavilhanas said that hunting occurs throughout the year (Table 1). The most cited motivation for hunting was subsistence, but trade was also mentioned (22\% of all interviewees). A majority of all interviewees (65\%) admitted to having consumed manatee meat (Table 1), at least in their youth, and some interviewees from Anavilhanas said they knew of small markets where manatee meat was sold. Most claimed that manatee fat can be used in cooking ( 77 and $91 \%$ in Anavilhanas and Tapajós, respectively), and medicinal use was cited frequently in Tapajós (32\%; Table 1).

\section{Discussion}

The traditional knowledge of the riverine people interviewed corroborated the findings of other researchers (Best, 1984; Arraut et al., 2010) and highlighted the influence of seasonal ecosystem changes on the distribution of Amazonian manatees:

During high-water periods, they eat in the shallow places, at night.

In the summer (low-water season) we cannot find it, there is no food, nothing. They only surface in deep areas.

Although the interviewees' level of knowledge of manatee reproduction varied, some described the reproductive behaviour of a female, with several males, as described by Pereira (1944). Several interviewees reported the birth of calves, confirming the observations of Best (1982): it occurs as waters rise, when there is greater availability of plants. In agreement with Rosas (1994), interviewees reported that manatees were usually solitary or with calves. However, they also described having seen large groups of manatees, especially in low-water seasons, in refuges. Other types of aggregations have been reported at feeding sites (Best, 1982) and during the reproductive period (Pereira, 1944; Souza, 2015). 
TABLE 2 List of plant species in the diet of the Amazonian manatee, as reported during interviews with riverine people in Anavilhanas National Park (A) and protected areas in the Tapajós region (T), complemented with reports from the literature.

\begin{tabular}{|c|c|c|c|}
\hline Species & Vernacular name & Growth form & Locality \\
\hline \multicolumn{4}{|l|}{ Apocynaceae } \\
\hline Mesechites trifida (Jacq.) Müll. Arg. ${ }^{1,2}$ & Cipó & Vine & A \\
\hline Tassadia berteriana (Spreng.) W.D. Stevens $s^{1,2}$ & Cipó-icica & Vine & $\mathrm{A}, \mathrm{T}$ \\
\hline \multicolumn{4}{|l|}{ Araceae } \\
\hline Lemna minuta Kunth & Murerizinho & Free floating & A \\
\hline Montrichardia arborescens (L.) Schott ${ }^{3}$ & Aninga & Emergent & $\mathrm{T}$ \\
\hline Montrichardia linifera (Arruda) Schott & Aninga & Emergent & $\mathrm{T}$ \\
\hline Pistia stratiotes L. ${ }^{1,2,3,4}$ & Aguapé flor d'água & Free floating & $\mathrm{A}, \mathrm{T}$ \\
\hline \multicolumn{4}{|l|}{ Cabombaceae } \\
\hline Cabomba aquatica Aubl. ${ }^{1,4}$ & Mururé-redondinho & Rooted submerged & $\mathrm{T}$ \\
\hline Cabomba furcata Schult. \& Schult.f. & Samambaia & Rooted submerged & $\mathrm{T}$ \\
\hline \multicolumn{4}{|l|}{ Asteraceae } \\
\hline Mikania micrantha Kunth & Batatarana & Vine & A \\
\hline \multicolumn{4}{|l|}{ Convolvulaceae } \\
\hline Ipomoea alba L. & Batatarana & Vine & A \\
\hline Ipomoea sp. ${ }^{2,3,4}$ & Batatarana & Vine & $\mathrm{T}$ \\
\hline \multicolumn{4}{|l|}{ Curcubitaceae } \\
\hline Cayaponia cruegeri (Naudin) Cogn., ${ }^{1,2}$ & Jamarurana & Vine & A \\
\hline Pteropepon deltoideus Cogn. & & Vine & A \\
\hline \multicolumn{4}{|l|}{ Cyperaceae } \\
\hline Eleocharis confervoides (Poir.) Steud. & Amã & Rooted submerged & $\mathrm{T}$ \\
\hline Eleocharis fluctuans (L.T. Eiten) E.H. Roalson & Capim de fundo, capinzinho & Rooted submerged & $\mathrm{T}$ \\
\hline Eleocharis interstincta (Vahl) Roem. \& Schult ${ }^{1,5}$ & Junco & Amphibious & $\mathrm{T}$ \\
\hline Eleocharis minima Kunth & Capim de fundo, capinzinho & Terrestrial, submerged & $\mathrm{A}, \mathrm{T}$ \\
\hline Eleocharis mutata (L.) Roem. \& Schult. & Junquinho & Amphibious & $\mathrm{T}$ \\
\hline Eleocharis plicarhachis (Griseb.) Svenson & Junco & Amphibious & $\mathrm{T}$ \\
\hline Scleria gaertneri Raddi & Tiririca & Terrestrial & $\mathrm{T}$ \\
\hline \multicolumn{4}{|l|}{ Euphorbiaceae } \\
\hline Alchornea discolor Poepp. & Supiarana & Trees \& shrubs & A \\
\hline \multicolumn{4}{|l|}{ Fabaceae } \\
\hline Aeschynomene L. ${ }^{1,2}$ & Dormideira & Amphibious & A \\
\hline Clitoria glycinoides DC. & Feijão de praia & Vine & A \\
\hline Sesbania exasperate Kunth & Paricá & Trees \& shrubs & $\mathrm{T}$ \\
\hline Cymbosema roseum Benth. & Feijão graúdo & Vine & A \\
\hline Vigna lasiocarpa (Mart. ex Benth.) Verdc. & Feijãoarana & Vine & $\mathrm{A}, \mathrm{T}$ \\
\hline \multicolumn{4}{|l|}{ Hydrocaritaceae } \\
\hline Apalanthe granatensis (Bonpl.) Planch & Samambaia & Rooted submerged & $\mathrm{T}$ \\
\hline $\begin{array}{l}\text { Limnobium laevigatum (Humb. \& Bonpl. ex Willd.) } \\
\text { Heine }\end{array}$ & Mureru & Free floating submerged & A \\
\hline \multicolumn{4}{|l|}{ Lentibulariaceae } \\
\hline Utricularia breviscapa C. Wright ex Griseb. & Samambaia, lodo & Free floating submerged & $\mathrm{T}$ \\
\hline Utricularia foliosa L. & Lodo, samambaia & Free floating submerged & $\mathrm{A}, \mathrm{T}$ \\
\hline \multicolumn{4}{|l|}{ Mayacaceae } \\
\hline Mayaca fluviatilis Aubl. & Mureré do campo & Rooted submerged & $\mathrm{T}$ \\
\hline \multicolumn{4}{|l|}{ Menyanthaceae } \\
\hline Nymphoides indica (L.) Kuntze & Apé & $\begin{array}{l}\text { Rooted submerged, with floating } \\
\text { leaves }\end{array}$ & $\mathrm{T}$ \\
\hline \multicolumn{4}{|l|}{ Nymphaeaceae } \\
\hline Nymphaea potamophila Wiersema & Apézinho & $\begin{array}{l}\text { Rooted submerged, with floating } \\
\text { leaves }\end{array}$ & $\mathrm{T}$ \\
\hline Nymphaea rudgeana G. Mey. & Apé & $\begin{array}{l}\text { Rooted submerged, with floating } \\
\text { leaves }\end{array}$ & $\mathrm{T}$ \\
\hline \multicolumn{4}{|l|}{ Passifloraceae } \\
\hline Passiflora misera Kunth & Maracujázinho & Vine & A \\
\hline Passiflora pohlii Mast. & Maracujázinho & Vine & A \\
\hline
\end{tabular}


Table 2 (Cont.)

\begin{tabular}{|c|c|c|c|}
\hline Species & Vernacular name & Growth form & Locality \\
\hline \multicolumn{4}{|l|}{ Plantaginaceae } \\
\hline Bacopa reflexa (Benth.) Edwall & Samambaia d'água & Rooted submerged & $\mathrm{T}$ \\
\hline \multicolumn{4}{|l|}{ Poaceae } \\
\hline Echinochloa sp. P. Beauv & Canarana & Amphibious & A \\
\hline Echinochloa polystachya (Kunth) Hitchc. ${ }^{1,2,3,4}$ & Canarana & Amphibious & $\mathrm{A}, \mathrm{T}$ \\
\hline Hymenachne amplexicaulis (Rudge) Nees ${ }^{1,2,3,4}$ & Bucho de pato & Emergent & $\mathrm{A}, \mathrm{T}$ \\
\hline Leersia hexandra Sw. ${ }^{1,2,3}$ & Capim navalha & Amphibious & $\mathrm{T}$ \\
\hline Louisiella elephantipes (Nees ex Trin.) Zuloaga & Capim & Amphibious & $\mathrm{T}$ \\
\hline Luziola subintegra Swallen & Capim buchudo & Amphibious & $\mathrm{T}$ \\
\hline Oryza glumaepatula Steud & Arroz, capim de arroz & Emergent & $\mathrm{A}, \mathrm{T}$ \\
\hline Panicum dichotomiflorum Michx. ${ }^{2}$ & Capim & Amphibious & $\mathrm{T}$ \\
\hline Paspalum repens P.J. Bergius ${ }^{1,2,3,4}$ & Membeca, premembeca & Amphibious & $\mathrm{A}, \mathrm{T}$ \\
\hline \multicolumn{4}{|l|}{ Polygonaceae } \\
\hline Polygonum acuminatum Kunth & Tabacarana, boieira & Amphibious & $\mathrm{T}$ \\
\hline Coccoloba pichuna Huber & Maracarana & Trees \& shrubs & A \\
\hline \multicolumn{4}{|l|}{ Pontederiaceae } \\
\hline Eichhornia azurea (Sw.) Kunth ${ }^{1,3}$ & Mureru & $\begin{array}{l}\text { Rooted submerged, with floating } \\
\text { leaves }\end{array}$ & $\mathrm{T}$ \\
\hline Eichhornia crassipes (Mart.) Solms ${ }^{1,2,3,4,5}$ & Mureru & Free floating & $\mathrm{A}, \mathrm{T}$ \\
\hline Pontederia rotundifolia L.f. ${ }^{1,2}$ & Mureru & Free floating & $\mathrm{T}$ \\
\hline \multicolumn{4}{|l|}{ Pteridaceae } \\
\hline Ceratopteris pteridoides (Hook.) Hieron. ${ }^{2}$ & Mureru véu & Free floating & A \\
\hline \multicolumn{4}{|l|}{ Salvinaceae } \\
\hline Azolla filiculoides Lam. & Mureruzinho & Free floating & $\mathrm{T}$ \\
\hline Salvinia auriculata Aubl. ${ }^{1,3,4}$ & Lentilha d'água & Free floating & $\mathrm{A}, \mathrm{T}$ \\
\hline Salvinia sp. & Mureru & Free floating & A \\
\hline \multicolumn{4}{|l|}{ Solanaceae } \\
\hline Schwenckia grandiflora Benth. & Cipó & Trees \& shrubs & A \\
\hline Solanum subinerme Jacq. & Jurubeba & Trees \& shrubs & A \\
\hline \multicolumn{4}{|l|}{ Vitaceae } \\
\hline Cissus erosa Rich. & Cipó & Vine & $\mathrm{A}, \mathrm{T}$ \\
\hline \multicolumn{4}{|l|}{ Urticaceae } \\
\hline Cecropia sp. Loefl ${ }^{5}$ & Embaúba & Emergent & $\mathrm{T}$ \\
\hline Unknown species & Lodo/lama & & $\mathrm{A}, \mathrm{T}$ \\
\hline
\end{tabular}

${ }^{1}$ Franzini et al. (2013).

${ }^{2}$ Guterres-Pazin et al. (2014).

${ }^{3}$ Best (1981)

${ }^{4}$ Colares \& Colares (2002).

${ }^{5}$ Best \& Teixeira (1982).

\section{Feeding habits}

From the interviews and the collection of plants both in Anavilhanas and the Tapajós region (Crema, 2017), 60 food species were recorded, of which $40(67 \%)$ had not previously been known to be food plants (Best, 1981; Colares \& Colares, 2002; Zaniolo, 2006; Franzini et al., 2013; Guterres-Pazin et al., 2014), indicating there is a significant amount of traditional knowledge yet to be gathered on the feeding ecology of wild Amazonian manatees. In contrast with findings that plants of the families Cyperaceae and Poaceae are the most important food plants for the Amazonian manatee (Best, 1981; Colares \& Colares, 2002; Guterres-Pazin et al., 2014), in Anavilhanas the cognitive salience index indicated that a number of other species are important, including vines and shrubs. These become accessible to manatees during the high-water season, when shrubs are flooded and the lower leaves of vines become accessible (Crema, 2017).

In Anavilhanas there is no evidence of plant consumption by manatees during the low-water season. However, a study in central Amazonian igapós identified a variety of species in the faeces and stomach contents of manatees in this season (Guterres-Pazin et al., 2014). Anavilhanas does not have significant availability of food for aquatic herbivores during most of the year (Crema, 2017). In the low-water season some plant species predominate only in permanently wet places, inaccessible to the manatee. During high waters, when food is more available, manatees accumulate fat to survive the dry season (Best, 1983). Thus, 
TABLE 3 Citation frequency, mean citation position on all lists, and cognitive salience index value of each plant species reported by interviewees from the vicinity of Anavilhanas National Park, and the Tapajós National Forest and Tapajós-Arapiuns Extractive Reserve as being a component of the diet of the Amazonian manatee, ordered by descending cognitive salience index. Only those species from Table 2 that were cited in more than one interview are listed here.

\begin{tabular}{|c|c|c|c|}
\hline Plants & $\begin{array}{l}\text { Citation } \\
\text { frequency }\end{array}$ & $\begin{array}{l}\text { Mean } \\
\text { citation } \\
\text { position }\end{array}$ & $\begin{array}{l}\text { Cognitive } \\
\text { salience } \\
\text { index }\end{array}$ \\
\hline \multicolumn{4}{|c|}{ Anavilhanas National Park } \\
\hline I. alba & 12 & 1.75 & 0.34 \\
\hline \multicolumn{4}{|l|}{ M. micrantha } \\
\hline T. berteriana & 12 & 2.58 & 0.23 \\
\hline \multicolumn{4}{|l|}{ M. trifida } \\
\hline C. pichuna & 9 & 2.33 & 0.19 \\
\hline Cyperaceae spp. & 8 & 2.25 & 0.17 \\
\hline O. glumaepatula & 13 & 4.00 & 0.16 \\
\hline$V$. lasiocarpa & 7 & 3.57 & 0.10 \\
\hline S. auriculata & 5 & 2.60 & 0.10 \\
\hline E. polystachya & 5 & 4.00 & 0.06 \\
\hline U. foliosa & 4 & 4.50 & 0.04 \\
\hline$P$. repens & 3 & 5.00 & 0.03 \\
\hline S. subinerme & 2 & 5.00 & 0.03 \\
\hline Periphyton & 2 & 5.00 & 0.02 \\
\hline \multicolumn{4}{|c|}{ Tapajós protected areas } \\
\hline N. potamophila & 43 & 1.88 & 0.38 \\
\hline \multicolumn{4}{|l|}{ N. rudgeana } \\
\hline E. minima & 31 & 2.01 & 0.24 \\
\hline E. fluctuans & 11 & 1.81 & 0.10 \\
\hline O. glumaepatula & 17 & 3.05 & 0.09 \\
\hline M. linifera & 15 & 3.06 & 0.08 \\
\hline \multicolumn{4}{|l|}{ M. arborescens } \\
\hline E. polystachya & 18 & 3.83 & 0.08 \\
\hline U. foliosa & 18 & 3.83 & 0.08 \\
\hline H. amplexicaulis & 14 & 3.14 & 0.07 \\
\hline Ipomea sp. & 10 & 9.90 & 0.04 \\
\hline E. azurea & 10 & 4.00 & 0.04 \\
\hline \multicolumn{4}{|l|}{ E. crassipes } \\
\hline E. confervoides & 7 & 3.00 & 0.04 \\
\hline Cyperaceae ssp. & 5 & 3.40 & 0.02 \\
\hline L. elephantipes & 5 & 3.80 & 0.02 \\
\hline V. lasiocarpa & 5 & 4.20 & 0.02 \\
\hline S. gaertneri & 3 & 3.33 & 0.01 \\
\hline Cecropia spp. & 2 & 3.50 & 0.01 \\
\hline
\end{tabular}

the manatee exhibits selective or opportunistic feeding behaviour, depending on the availability of plants, which is related to the flood pulse (Colares \& Colares, 2002; Guterres-Pazin et al., 2014). According to the traditional knowledge of riverine people, in the Tapajós region the manatee selects rooted plants with floating leaves and, although it feeds preferentially on leaves, it may also dig up the lake bed around Nymphaea spp. to consume their corms and roots. In Tapajós many lakes retain sufficient water during the low-water season to support the persistence of both submerged macrophytes and manatees (Crema, 2017).

\section{Hunting}

As already reported (Pereira, 1944; Marmontel et al., 2012), manatee hunters have specific knowledge about the species. At both study sites comidias are an indicator for locating manatees during the high-water season. Hunting of the Amazonian manatee is related to its variation in habitat use (Calvimontes \& Marmontel, 2010; Souza, 2015). Some authors (Best, 1982; Calvimontes \& Marmontel, 2010), and the interviewees in our study, reported that during low water hunting is restricted to pools where several manatees congregate and members of the community fish, increasing the potential for encounters between them (Mayaka et al., 2013).

As cited for other localities (Marmontel et al., 2012), interviewees confirmed that harpoon hunting is the primary cause of death of Amazonian manatees, followed by incidental catches in fishing nets (Aguilar, 2007; Zaniolo, 2006), particularly of vulnerable young individuals. Such impacts can substantially reduce populations (Rosas, 1994).

In 1938 peak demand for T. inunguis hide led to the hunting of c. 16,00o manatees (Domning, 1982; Antunes et al., 2016). Since the creation of the Fauna Protection Act in 1967 there has been no record of this type of activity. Therefore, the motivation for hunting is small-scale commercialization and an appreciation, or tradition, of manatee meat consumption (Calvimontes \& Marmontel, 2010; da Silva et al., 2017).

\section{The use of protected areas by Amazonian manatees}

The locations shown in Fig. 1 indicate places of rest, refuge or foraging for the Amazonian manatee, information fundamental for defining sites for release and management of the species. Releases of rehabilitated manatees to recolonize Amazonian water bodies were carried out in 2007 in Tapajós-Arapiuns Extractive Reserve, during 2008-2009 in Rio Cuieiras (Rio Negro Basin), in 2012 in Amanã Reserve, and in 2016-2018 in Piagaçu-Purus Reserve (Diogo Souza, pers. comm.). Knowledge of places with suitable foraging resources can provide alternative locations for the release of manatees.

Although the studied areas are protected by law, in Anavilhanas $30 \%$ of the respondents reported at least one episode of manatee hunting during the 2 years preceding our research. Anavilhanas has a small human population, historically characterized by inter-ethnic conflicts, loss of cultural identity, and economic hardship that made exploitation of natural resources essential for survival (Leonardi, 
1999). The Park receives a large number of visitors, and its proximity to urban centres increases its vulnerability to anthropogenic disturbances (Tardio \& da Silveira, 2015) and illegal activities (ICMBio, 2017).

The number of hunting events recorded in recent years is fewer in Tapajós, which may be attributed to fear of reporting illegal events, or a reduction in hunting practices, strengthened by traditional knowledge. The Tapajós region comprises sustainable use areas, where rational and sustainable exploitation is permitted. The creation of the Tapajós-Arapiuns Extractive Reserve was driven by a popular movement (IBAMA, 2004; ICMBio, 2014) and the inhabitants are considered to be traditional, having a history of multi-generational residence and sustainable use of natural resources (Berkes et al., 200o).

In Anavilhanas traditional knowledge highlighted the importance of vines as a component of manatee diet, despite being available only during the high-water season. As in this region there is little or no food available for aquatic herbivores during flooding (Crema, 2017), manatees may move to areas with higher food supply, such as the Rio Solimões floodplain, c. $130 \mathrm{~km}$ away, which is rich in aquatic plants (Piedade et al., 2010). The Amazonian manatee performs annual migrations of tens of kilometres between ecosystems (Arraut et al., 2010). Thus, conservation initiatives for T. inunguis in Anavilhanas need to be broadened to a larger area to ensure its protection.

Elsewhere, environmental conservation has been found to be related to education level (Fiallo \& Jacobson, 1995). Through involving fishers in ecotourism and research, the Mamirauá Institute of Sustainable Development and Projeto Boto have promoted positive attitudes towards the conservation of the Amazon river dolphin Inia geoffrensis (Mintzer et al., 2015). We have discussed the nature of effective manatee conservation with protected area authorities, emphasizing that a suitable strategy must not only limit hunting but also increase the involvement of riverine people in management activities. Studies are also required to determine the range of the manatee, so that joint actions between all protected area stakeholders can be planned. Combining the management of these areas with the active participation of the local population is one of the greatest challenges and opportunities for conservation (Fragoso et al., 2000; Shepard et al., 2010).

The diet of the Amazonian manatee differs between igapós because of differences in the floristic characteristics of each. Riverine people in the vicinity of Anavilhanas and Tapajós protected areas have detailed knowledge of the biology of the Amazonian manatee and of plant species that had not been previously reported to be part of the manatee's diet. Improving social participation, including this important knowledge, is fundamental for the conservation management of the Amazonian manatee and its habitat.
Acknowledgements We thank Eliene Cruz and Graziela Balassa for the map figures, the HUAM and all those who have helped with this study. Financial support was provided by Instituto Chico Mendes de Conservação da Biodiversidade, Grupo Ecologia Monitoramento e Uso Sustentável de Áreas Úmidas; Adaptações da Biota Aquática Amazônica II, Associação Amigos do Peixe-boi, and Projeto Petrobras Socioambiental. Field work was carried out under collecting permits CEUC/SDS 70/2014 and SISBIO 25347/2011, provided by Centro Estadual de Unidades de Conservação of Amazonas State and Instituto Chico Mendes de Conservação da Biodiversidade, respectively.

Author contributions Project design: LCC, VMFS and MTFP; data collection and writing: LCC; data interpretation and revision of the text: all authors.

\section{Conflicts of interest None.}

Ethical standards Research was approved by the Human Research Ethics Committee of the National Institute of Amazonian Research (\#501,473/2013) and followed national laws.

\section{References}

Aguilar, C.V.C. (2007) Etnoconhecimento do peixe-boi amazônico (Trichechus inunguis): uso tradicional por ribeirinhos na Reserva Extrativista Tapajós-Arapiuns e Floresta Nacional do Tapajós, Pará. MSc thesis. Universidade Federal do Pará, Pará, Brazil.

Albuquerque, U.P., Ramos, M.A., Lucena, R.F.P. \& Alencar, N.L. (2014) Methods and techniques used to collect ethnobiological data. In Methods and Techniques in Ethnobiology and Ethnoecology (eds U.P. Albuquerque, L.V.F. Cunha, R.F.P. Lucena \& R.R.N. Alves), pp. 15-37. Springer, New York, USA.

Amaral, R.S., Da Silva, V.M.F. \& Rosas, F.C.W. (2010) Body weight/ length relationship and mass estimation using morphometric measurements in Amazonian manatees Trichechus inunguis (Mammalia: Sirenia). Marine Biodiversity Records, 3, 105-108.

Antunes, A.P., Fewster, R.M., Venticinque, E.M., Peres, C.A., Levi, T., Rohe, F. \& Shepard, JR, G.H. (2016) Empty forest or empty rivers? A century of commercial hunting in Amazonia. Science Advances, 2, e1600936.

Arraut, E.M., Marmontel, M., Mantovani, J.E., Novo, E.M.L., Macdonald, D.W. \& Kenward, R.E. (2010) The lesser of two evils: seasonal migrations of Amazonian manatees in the Western Amazon. Journal of Zoology, 280, 247-256.

Berkes, F., Colding, J. \& Folke, C. (2000) Rediscovery of traditional ecological knowledge as adaptative management. Ecological Applications, 10, 1251-1262.

Best, R.C. (1981) Foods and feeding habits of wild and captive Sirenia. Mammal Review, 11, 3-29.

BEST, R.C. (1982) A salvação de uma espécie: novas perspectivas para o peixe-boi da Amazônia. Public Division of Aquatic Mammal Biology, 14, 1-9.

Best, R.C. (1983) Apparent dry-season fasting in Amazonian manatees (Mammalia: Sirenia). Biotropica, 15, 61-64.

BEST, R.C. (1984) The aquatic mammals and reptiles of the Amazon. In The Amazon: Limnology and Landscape Ecology of a Mighty Tropical River and its Basin (ed. H Sioli), pp. 370-412. Kluwer Academic Publishers, Dordrecht, The Netherlands.

Best, R.C. \& Teixeira, D.M. (1982) Notas sobre a distribuição e "status" aparente dos peixes-bois (Mammalia: Sirenia) nas costas amapenses brasileiras. Boletim da Fundação Brasileira para Conservação da Natureza, 17, 41-47. 
Borgatti, S.P. (1998) Elicitation methods for cultural domain analysis. In The Ethnographer's Toolkit (eds J.J. Schensul \& M.D. Le Compte), pp. 2-26. Altamira Press, Walnut Creek, USA.

Calvimontes, J. \& Marmontel, L.M. (2010) Estudios etnobiológicos sobre el manatí amazónico (Trichechus inunguis Natterer 1883) y su conservación en la Reserva de Desarrollo Sostenible Amanã, Brasil. In Sistemas Biocognitivos Tradicionales: Paradigmas en la Conservación Biológica y el Fortalecimiento Cultural (eds A.M. Fuentes, M.T.P. Silva, R.M. Méndez, R.V. Azúa, C.O.M. Mejí \& T.V.G. Santillan), pp. 396-402. Universidad Autónoma del Estado de Hidalgo, Pachuca, Mexico.

CITES (2017) Conventionon International Trade in Endangered Species of Wild Fauna and Flora. Appendices I, II and III. Http://cites.org/eng/app/appendices.php [accessed 1 August 2018].

Colares, I.G. \& Colares, E.P. (2002) Food plants eaten by Amazonian manatees (Trichechus inunguis, Mammalia: Sirenia). Brazilian Archives of Biology and Technology, 45, 67-72.

Crema, L.C. (2017) Characterization of clear and blackwater igapós and their food availabilities for the Amazon manatee (Trichechus inunguis). PhD thesis. Instituto Nacional de Pesquisas da Amazônia, Manaus, Brazil.

da Silva, V.M.F., Rosas, F.C.W. \& Cantanhede, A.M. (2008) Peixe-boi da Amazônia, Trichechus inunguis (Natterer, 1883). In Livro Vermelho da Fauna Brasileira Ameaçada de Extinção (eds A.B.M. Machado, G.M. Drummond \& A.P. Paglia), pp. 816-818. Ministério do Meio Ambiente e Fundação Biodiversitas, Belo Horizonte, Minas Gerais, Brazil.

Da Silva, V.M.F., Shepard, G. \& do Carmo, N.M. (2017) Os Mamíferos Aquáticos: Lendas, Usos e Interações com as Populações Humanas na Amazônia Brasileira. In Olhares cruzados sobre as relações entre seres humanos e animais silvestres na Amazônia (Brasil, Guiana Francesa) (eds M. Guillaume \& F.V. Velden), pp. 193-226. EDUA, Manaus, Amazonas, Brazil.

Domning, D.P. (1982) Commercial exploitation of manatees Trichechus in 1785-1973. Biological Conservation, 22, 101-126.

Fabricius, C. \& Косн, E. (2004) Rights, Resources and Rural Development: Community-Based Natural Resource Management in Southern Africa. Earthscan, London, UK.

Fiallo, E.A. \& JACOBSON, S.K. (1995) Local communities and protected areas: attitudes of rural residents towards conservation and Machalilla National Park, Ecuador. Environmental Conservation, 22, 241-249.

Forzza, R.C., Costa, A., Walter, B.M.T., Pirani, J.R., Morim, M.P., Queiroz, L.P. et al. (2016) Angiospermas na Lista de Espécies da Flora do Brasil. Jardim Botânico do Rio de Janeiro, Rio de Janeiro, Brazil.

Fragoso, J.M.V., Silvius, K.M. \& Villa-Lobos, M. (2000) Wildife Management at the Rio das Mortes Xavante Reserve, MT: Integrating Indigenous Culture and Scientific Method for Conservation. Volume 4. WWF, Brasilia, Brazil.

Franzini, A., Castelblanco-Martinez, N., Rosas, F.C.W. \& da SiLVA, V.M.F. (2013) What do local people know about Amazonian manatees? Traditional ecological knowledge of Trichechus inunguis in the oil province of Urucu, AM, Brazil. Brazilian Journal for Nature Conservation, 11, 75-80.

Guterres-Pazin, M., Marmontel, M., Rosas, F.C.W., Pazin, V.F.V. \& Venticinque, E.M. (2014) Feeding ecology of the Amazonian manatee (Trichechus inunguis) in the Mamirauá and Amanã Sustainable Development Reserves. Aquatic Mammals, 40, 139-149.

Huntington, H.P. (2000) Using traditional ecological knowledge in science: methods and applications. Ecological Applications, 10, 1270-1274.
IBAMA (2004) Plano de Manejo da Floresta Nacional do Tapajós Volume I Informações Gerais. Ministério do Meio Ambiente, Brasília, Brazil.

ICMBIO (2011) Plano de ação nacional para a conservação dos sirênios: peixe-boi-da Amazônia: Trichechus inunguis e peixe-boi-marinho: Trichechus manatus (eds M.C.M. Andrade, F.O. Luna \& M.L. Reis). Minsitério do Meio Ambiente, Brasília, Brazil.

ICMBIo (2014) Plano de Manejo da Reserva Extrativista Tapajós-Arapiuns. Ministério do Meio Ambiente, Santarém, Pará, Brazil.

ICMBio (2017) Plano de Manejo Parque Nacional de Anavilhanas. Ministério do Meio Ambiente, Novo Airão, Amazonas, Brazil.

Junk, W.J. (1986) Aquatic plants of the Amazon system. In The Ecology of River Systems (eds B.R. Davies \& K.F. Walker), pp. 319-338. Dr. W. Junk Publishers, Dordrecht, The Netherlands.

JunK, W.J. \& Da Silva, V.M.F. (1997) Mammals, Reptiles and Amphibians. In The Central Amazon Floodplain: Ecology of a Pulsing System (ed. W.J. Junk), pp. 409-417. Springer Verlag, Berlin, Germany.

Leonardi, V. (1999) Os historiadores e os rios: Natureza e Ruína na Amazônia Brasileira. Paralelo 15/Ed.Unb, Brasília, Brazil.

Lima-Ayres, D. (1992) The social category caboclo: history, social organization, identity and outsider's local social classification of the rural population of an Amazonian region. $\mathrm{PhD}$ thesis. University of Cambridge, Cambridge, UK.

Marmontel, M., Rosas, F.C.W. \& Kendall, S. (2012) The Amazonian manatee. In Sirenian Conservation: Issues and Strategies in Developing Countries (eds E.M. Hines, J.E. Reynolds III, L.V. Aragones, A.A. Mignucci-Giannoni \& M. Marmontel), pp. 47-53. University Press of Florida, Gainesville, USA.

Marmontel, M., de Souza, D. \& Kendall, S. (2016) Trichechus inunguis. In The IUCN Red List of Threatened Species 2016: e.T22102A43793736. Http://dx.doi.org/10.2305/IUCN.UK.2016-2. RLTS.T22102A 43793736.en [accessed 1 August 2018].

Mayaka, T.B., Awah, H.C. \& Ajonina, G. (2013) Conservation status of manatee (Trichechus senegalensis Link 1795) in Lower Sanaga Basin, Cameroon: an ethnobiological assessment. Tropical Conservation Science, 6, 521-538.

Mintzer, V.J., Schmink, M., Lorenzen, K., Thomas, F.K., Martin, A.R. \& DA Silva, V.M.F. (2015) Attitudes and behaviours toward Amazon River dolphins (Inia geoffrensis) in a sustainable use protected area. Biodiversity and Conservation, 24, 247-269.

MMA (2014) Lista Nacional Oficial de Espécies da Fauna Ameaçadas de Extinção. Http://www.icmbio.gov.br/portal/images/stories/ biodiversidade/fauna-brasileira/avaliacao-do-risco/PORTARIA_N \%C2\%BA_444_DE_17_DE_DEZEMBRO_DE_2014.pdf [accessed 11 May 2016].

Pereira, M.N. (1944) O peixe-boi da Amazônia. Boletim do Ministério da Agricultura, 33, 21-95.

Piedade, M.T.F., Ferreira, C.S. \& Franco, A.C. (2010) Estrategias reproductivas de la vegetación y sus respuestas al pulso de la inundación en las zonas inundables de la Amazonía Central. Ecosistemas, 19, 52-66.

RAJAMANI, L. (2013) Using community knowledge in data-deficient regions: conserving the vulnerable dugong Dugong dugon in the Sulu Sea, Malaysia. Oryx, 47, 173-176.

Rosas, F.C.W. (1994) Biology, conservation and status of the Amazonian manatee Trichechus inunguis. Mammal Review, 24, 49-59.

Shepard, Jr, G.H., Rummenhoeller, K., Ohl-Schacherer, J. \& Yu, D.W. (2010) Trouble in paradise: indigenous populations, anthropological policies, and biodiversity conservation in Manu National Park, Peru. Journal of Sustainable Forestry, 29, 252-301. 
Souza, D.A. (2015) Peixe-boi da Amazônia (Trichechus inunguis NATTERER 1883): mortalidade e uso do habitat na reserva de desenvolvimento sustentável Piagaçu-Purus, Amazonas, Brasil. MSc thesis. Instituto Nacional de Pesquisas da Amazônia, Manaus, Amazonas, Brazil.

Sutrop, U. (2001) List task and a cognitive salience index. Field Methods, 13, 263-276.
Tardio, B.M.R. \& Da Silveira, R. (2015) The role of forest structure and human occupation in structuring mammal assemblages in oligotrophic ecosystems of Central Amazonia. Austral Ecology, 40, 318-330.

Zaniolo, G.R. (2006) Etnoconhecimento do peixe-boi amazônico Trichechus inunguis (Natterer, 1883) pelos pescadores de Novo Airão, Amazonas, Brasil. MSc thesis. Universidade Federal do Amazonas, Manaus, Amazonas, Brazil. 